University of Nebraska - Lincoln

DigitalCommons@University of Nebraska - Lincoln

USDA National Wildlife Research Center - Staff Publications
U.S. Department of Agriculture: Animal and Plant Health Inspection Service

January 2007

\title{
Avian Use of Rural Roadsides with Cattail (Typha spp.)
}

Bryan Safratowich

North Dakota State University, Fargo

George M. Linz

USDA/APHIS/WS National Wildlife Research Center, george_m_linz@yahoo.com

William H. Bleier

North Dakota State University, Fargo

H. Jeffrey Homan

USDA/APHIS/WS, National Wildlife Research Center, Great Plains Field Station

Follow this and additional works at: https://digitalcommons.unl.edu/icwdm_usdanwrc

Part of the Environmental Sciences Commons

Safratowich, Bryan; Linz, George M.; Bleier, William H.; and Homan, H. Jeffrey, "Avian Use of Rural Roadsides with Cattail (Typha spp.)" (2007). USDA National Wildlife Research Center - Staff Publications. 784.

https://digitalcommons.unl.edu/icwdm_usdanwrc/784

This Article is brought to you for free and open access by the U.S. Department of Agriculture: Animal and Plant Health Inspection Service at DigitalCommons@University of Nebraska - Lincoln. It has been accepted for inclusion in USDA National Wildlife Research Center - Staff Publications by an authorized administrator of DigitalCommons@University of Nebraska - Lincoln. 


\title{
Avian Use of Rural Roadsides with Cattail (Typha spp.)
}

\author{
BRYAN SAFRATOWICH ${ }^{1}$ \\ Department of Biological Sciences, North Dakota State University, Fargo 58105 \\ GEORGE M. LINZ \\ USDA/APHIS/WS, National Wildlife Research Center, Great Plains Field Station, 2110 Miriam Circle, Bismarck, \\ North Dakota 58501 \\ WILLIAM H. BLEIER \\ Department of Biological Sciences, North Dakota State University, Fargo 58105 \\ AND \\ H. JEFFREY HOMAN ${ }^{2}$ \\ USDA/APHIS/WS, National Wildlife Research Center, Great Plains Field Station, 2110 Miriam Circle, Bismarck, \\ North Dakota 58501
}

\begin{abstract}
We surveyed 30 roadsides in North Dakota's Prairie Pothole Region for birds and active nests between May and July 2001-2002. Each roadside transect was $1608 \mathrm{~m}$ and had $\geq 200$ linear meters of standing cattail (Typha spp.). We recorded 45 bird species; four species of Icteridae dominated the avifauna. Red-winged blackbirds (Agelaius phoeniceus) were both the most abundant species and most abundant nester, averaging 53 birds/10 ha $(\mathrm{se}=7.7)$ and 30 nests/10 ha $(\mathrm{se}=9.7)$. Among non-icterid species, song sparrow (Melospiza melodia) and common yellowthroat (Geothlypis trichas) ranked first and second consecutively in 2001 and 2002. Canonical correspondence analyses of species compositions indicated that species abundance was related to two roadside variables, length and water depth of cattail stands. Cattails added habitat diversity and acceptable conditions for wetland-dwelling avian species not typically found in rural roadsides outside of the Prairie Pothole Region. We documented use of roadsides by three species of grassland birds of national or regional conservation concern. Roadsides in North Dakota, although dominated mostly by generalist bird species with edge tolerance, may have some management potential for area-dependent grassland birds.
\end{abstract}

\section{INTRODUCTION}

Bird species that use roadside right-of-ways are generally tolerant of habitat fragmentation and thrive in small-sized patches of habitat. Research on avian use of roadside right-of-ways (hereafter, roadsides) has been conducted mostly in rural areas of central Illinois, central Iowa, Nebraska and Oklahoma (Hergenrader, 1962; Warner, 1992; Camp and Best, 1993; Camp and Best, 1994; Shochat et al., 2005). In these studies most birds were upland and grassland species. Among the most abundant species were brown-headed cowbird, dickcissel (Spiza americana), eastern kingbird, gray partridge, meadowlark (Sturnella spp.), mourning dove, northern mockingbird (Mimus polyglottos), red-winged blackbird, song sparrow and vesper sparrow (see Table 1 for scientific names). Most roadsides in the central U.S. have shallow slopes, which cause the bottom "ditch" portions to dry rapidly (Camp and Best, 1994). Cool-season grasses especially smooth brome (Bromus inermis) and Kentucky bluegrass (Poa pratensis) can withstand the stresses of growing in rural roadsides and often

\footnotetext{
${ }^{1}$ Present address: Bryan Safratowich, 3241 S. Michigan Ave. 440, Chicago, IL 60616

${ }^{2}$ Corresponding author: email: jeffrey.homan@aphis.usda.gov
} 
provide the bulk of vegetation cover (Camp and Best, 1993). Cattail (Typha spp.) vegetation is rarely encountered in roadsides outside of the Prairie Pothole Region and the influence of cattail vegetation on avian use of roadsides has not been studied.

Healthy stands of cattail occur along many of North Dakota's rural roadsides. Roadsides in North Dakota have steep slopes, which are effective at capturing drifting snow during winter and retaining and controlling water runoff during spring and summer. During extended periods of normal or above-normal annual precipitation, cattail will invade and colonize roadsides. From May through early July 2001-2002, we documented avian use of rural roadsides with cattail and assessed effects of physical and environmental roadside variables on avian species composition. We conducted the study in southeastern North Dakota, an area of intense agriculture production with an extensive network of rural roads.

\section{Methods \\ STUDY AREA}

Roadsides were located in Barnes, Ransom, Sargent and Stutsman counties using a combination of aerial photographs and onsite searches. The counties lie in a physiographic subregion of the Prairie Pothole Region called the Southern Drift Plain (Stewart, 1975). The topography was gently rolling ground moraine interspersed by lake plains and shallow-basined wetlands (potholes). Large tracts of mixed-grass prairie existed but most were heavily grazed. About $65 \%$ of the Southern Drift Plain was in cropland, mainly small grains, soybean and canola. The 30 roadsides we selected were along roads categorized as maintained gravel bed $(63 \%)$, unimproved (20\%) and asphalt (17\%). These percentages were similar with the overall composition of road types in the study area. To access fields and transport harvested agricultural products, the study area was heavily gridded with gravel roads and road-like trails that ran North-South and East-West. Roads and trails often bisected at 1608-m intervals. The vegetation cover of the 30 selected roadsides was primarily smooth brome and Kentucky bluegrass $(>75 \%$ of vegetative cover) with cattail vegetation covering about $20 \%$ of roadside area. On average the roadsides had three discreet stands of cattail totaling $456 \mathrm{~m}(\mathrm{sE}=33.5)$ in length and $8 \mathrm{~m}(\mathrm{sE}=1.2)$ in width. Average water depth of roadside cattail stands in 2001 and 2002 was $25 \mathrm{~cm}(\mathrm{SE}=2.9)$ and $5 \mathrm{~cm}(\mathrm{SE}=1.4)$, respectively. Stem density of standing cattail was similar over years, averaging $10 \mathrm{stems} / 0.25 \mathrm{~m}^{2}(\mathrm{sE}=0.2), 70 \%$ live and $30 \%$ dead. Height and density of grass vegetation was $45 \mathrm{~cm}(\mathrm{sE}=2.5)$ and $57 \mathrm{~cm}(\mathrm{sE}=3.1)$. Habitat surrounding the roadsides was primarily agricultural $(36 \%)$, wetland $(26 \%)$ and upland $(20 \%)$.

The region has lengthy unpredictable periods of above- and below normal precipitation that cause cyclic filling and drying of roadsides. The average 30-y annual precipitation was $49.5 \mathrm{~cm}$, with about 75\% occurring between April and September. In 2000 precipitation was above average $(57 \mathrm{~cm})$, followed by above average precipitation for spring and summer 2001 ( $5 \mathrm{~cm}$ above for March-July). A dry period from November 2001 to June 2002 resulted in below average precipitation $(7.5 \mathrm{~cm}$ below $)$.

ROADSIDE SELECTION AND SURVEYS

We selected 30 Public Land Survey System quarter sections $(804 \times 804 \mathrm{~m})$ bordered on two adjacent sides by roadsides with $\geq 200$ linear meters of cattail over the $1608-\mathrm{m}$ extent. The average width of the 30 roadsides was $13 \mathrm{~m}(\mathrm{sE}=0.6)$. The 30 roadsides were randomly selected from a pool of 42 that met the sample criteria. Twice annually, between 31 May and 2 July 20012002, we surveyed roadsides for birds and active nests. For convenience in data collection and to give observers time to rest during counts, each roadside was divided into two 804-m segments. A minimum of $1 \mathrm{~h}$ was spent per roadside, with two roadsides surveyed per day. Bird surveys began 
TABLE 1.-Density of birds (per 10 ha) counted along 1608-m transects in 30 roadsides with $\geq 200$ linear meters of cattail (Typha spp.) vegetation. The surveys were conducted in the Southern Drift Plain of North Dakota's Prairie Pothole Region in 2001 and 2002. Species are listed in descending order by average density over the two-year study

\begin{tabular}{|c|c|c|c|c|c|}
\hline \multirow[b]{2}{*}{ Species } & \multirow[b]{2}{*}{ Scientific name } & \multicolumn{2}{|c|}{2001} & \multicolumn{2}{|c|}{2002} \\
\hline & & Mean & Std. Error & Mean & Std. Error \\
\hline Red-winged blackbird & Agelaius phoeniceus & 58.8 & 5.81 & 47.9 & 5.25 \\
\hline Brown-headed cowbird & Molothrus ater & 9.6 & 2.25 & 22.8 & 4.55 \\
\hline Yellow-headed blackbird & Xanthocephalus xanthocephalus & 14.8 & 4.70 & 6.8 & 2.87 \\
\hline Common grackle & Quiscalus quiscula & 9.2 & 2.04 & 9.9 & 1.77 \\
\hline Song sparrow & Melospiza melodia & 4.3 & 1.65 & 7.5 & 1.42 \\
\hline Common yellowthroat & Geothlypis trichas & 3.8 & 0.70 & 5.2 & 1.19 \\
\hline Blue-winged teal & Anas discors & 2.6 & 0.63 & 2.7 & 0.92 \\
\hline Mourning dove & Zenaida macroura & 1.3 & 0.47 & 4.2 & 1.47 \\
\hline Gadwall & Anas strepera & 1.1 & 0.43 & 3.9 & 2.02 \\
\hline American goldfinch & Carduelis tristis & 3.0 & 1.78 & 1.1 & 0.56 \\
\hline Killdeer & Charadrius vociferous & 1.5 & 0.60 & 2.4 & 0.99 \\
\hline Mallard & Anas platyrhynchos & 2.2 & 0.70 & 1.7 & 1.07 \\
\hline Marsh wren & Cistothorus palustris & 1.5 & 0.72 & 2.2 & 0.97 \\
\hline American robin & Turdus migratorius & 1.0 & 0.42 & 2.5 & 1.07 \\
\hline Eastern kingbird & Tyrannus tyrannus & 0.8 & 0.32 & 2.3 & 1.18 \\
\hline Clay-colored sparrow & Spizella pallida & 1.1 & 0.49 & 1.3 & 0.77 \\
\hline Wild turkey & Meleagris gallopavo & 0 & & 1.7 & 1.73 \\
\hline Unidentified duck & Anatinae & 0.1 & 0.05 & 1.5 & 1.36 \\
\hline Western meadowlark & Sturnella neglecta & 0.1 & 0.10 & 1.4 & 0.74 \\
\hline Bobolink & Dolichonyx oryzivorus & 1.0 & 0.35 & 0.4 & 0.25 \\
\hline Barn swallow & Hirundo rustica & 0.7 & 0.43 & 0.6 & 0.36 \\
\hline Red-tailed hawk & Buteo jamaicensis & 0 & & 1.3 & 1.05 \\
\hline Unidentified sparrow & Emberizidae & 0.8 & 0.40 & 0.3 & 0.16 \\
\hline Western kingbird & Tyrannus verticalis & 0.2 & 0.14 & 0.9 & 0.71 \\
\hline Northern flicker & Colaptes auratus & 0.1 & 0.06 & 0.7 & 0.39 \\
\hline Northern shoveler & Anas clypeata & 0.4 & 0.41 & 0.3 & 0.21 \\
\hline American coot & Fulica americana & 0.3 & 0.18 & 0.3 & 0.18 \\
\hline Chipping sparrow & Spizella passerina & 0.2 & 0.14 & 0.4 & 0.39 \\
\hline Upland sandpiper & Bartramia longicauda & 0.3 & 0.22 & 0.3 & 0.22 \\
\hline Wilson's snipe & Gallinago delicata & 0.2 & 0.17 & 0.2 & 0.12 \\
\hline Orchard oriole & Icterus spurius & 0 & & 0.4 & 0.03 \\
\hline Savannah sparrow & Passerculus sandwichensis & 0 & & 0.4 & 0.27 \\
\hline Brown thrasher & Toxostoma rufum & 0.1 & 0.09 & 0.2 & 0.15 \\
\hline Eastern bluebird & Sialia sialis & 0.1 & 0.09 & 0.2 & 0.17 \\
\hline Vesper sparrow & Pooecetes gramineus & 0.2 & 0.13 & 0.1 & 0.06 \\
\hline Virginia rail & Rallus limicola & 0 & & 0.3 & 0.21 \\
\hline American bittern & Botaurus lentiginosus & 0.2 & 0.17 & 0 & \\
\hline Baltimore oriole & Icterus galbula & 0.1 & 0.10 & 0.1 & 0.05 \\
\hline Black tern & Chlidonias niger & 0.2 & 0.12 & 0 & \\
\hline Grasshopper sparrow & Ammodramus savannarum & 0.2 & 0.12 & 0 & \\
\hline Gray partridge & Perdix perdix & 0 & & 0.2 & 0.16 \\
\hline Great horned owl & Bubo virginianus & 0.2 & 0.17 & 0 & \\
\hline Sora & Porzana carolina & 0.2 & 0.14 & 0 & \\
\hline Black-capped chickadee & Poecile atricapillus & 0 & & 0.1 & 0.08 \\
\hline Ruddy duck & Oxyura jamaicensis & 0.1 & 0.10 & 0 & \\
\hline
\end{tabular}


TABLE 1.-Continued

\begin{tabular}{|c|c|c|c|c|c|}
\hline \multirow[b]{2}{*}{ Species } & \multirow[b]{2}{*}{ Scientific name } & \multicolumn{2}{|c|}{2001} & \multicolumn{2}{|c|}{2002} \\
\hline & & Mean & Std. Error & Mean & Std. Error \\
\hline Sharp-tailed grouse & Tympanuchus phasianellus & 0.1 & 0.09 & 0 & \\
\hline Tree swallow & Tachycineta bicolor & 0 & & 0.1 & 0.1 \\
\hline
\end{tabular}

at sunrise and ended no later than 4-h post sunrise. Two observers were used; one walked the road edge, which provided a panoramic view of the roadside, while the other walked the middle of the roadside. In addition to recording all visual observations, we stopped every $20 \mathrm{~m}$ to listen for birds. Vocal playbacks were used to help detect secretive retiring species, such as soras (Glahn, 1974). Birds that flew over the roadside or responded to playbacks from beyond the roadside were not counted. Surveys were not conducted during rain or wind velocities $>$ $45 \mathrm{~km} / \mathrm{h}$. Counts from the two surveys conducted each year were averaged and divided by roadside area. To facilitate comparisons with other studies and to convert numerous species from their fractional per roadside densities, bird densities were reported in 10-ha units (see Camp and Best, 1993; Camp and Best, 1994). Nest surveys were done on the same day as counts. In densely vegetated upland areas we used hockey sticks to sweep vegetation and reveal cryptic nests and flush incubating and brooding females. Cattail stands were searched by walkthroughs. We only counted nests with eggs or young. We recorded nest location, nesting species, nest substrate, number of eggs and young and number of brown-headed cowbird eggs.

\section{ROADSIDE HABITAT}

Following the daily bird surveys, we measured physical and environmental attributes of the roadsides. Roadside widths were measured, along with number of cattail stands and their width and length. Additionally, we measured water depth and densities of living and dead cattail stems every $32 \mathrm{~m}$ after a random start along a lengthwise transect in the middle of each stand. Noncattail roadside vegetation was placed in an "upland" category. In 2002 we identified upland vegetation to species and measured density and height at foreslope, bottom and backslope. Grass density was estimated using a Robel pole viewed from the four cardinal directions at a height of $1 \mathrm{~m}$ and a distance of $1.5 \mathrm{~m}$ (Robel et al., 1970; Camp and Best, 1994). Vegetation height was measured with a meter stick. Lastly, road type and adjacent habitats were recorded. These variables were collected on the same day that counts and nest surveys were done.

\section{SPECIES COMPOSITION OF ROADSIDES}

We used canonical correspondence analysis (CCA) to evaluate roadside variables with patterns of abundance-weighted species composition (ter Braak, 1986; Palmer, 1993). An assumption of CCA is that species abundance has a unimodal response (i.e., bell-shaped distribution curve) to environmental variables (Palmer, 1993). To test for unimodality of species responses before conducting the CCA, we used a detrended correspondence analysis (ter Braak, 1995). Both the detrended correspondence analysis and the CCAs were done using CANOCO 4.0 (ter Braak and Smilauer, 1998). A separate CCA was done for 2001 and 2002. Species that were found infrequently (less than two roadsides per year) were excluded from the analysis to reduce noise and enhance the ability of the CCA to detect species patterns (McCune et al., 2002). Forward selection was used to determine which roadside variables were used in the CCAs (ter Braak and Verdonschot, 1995; Palmer, 1993). To provide equal weighting among the environmental variables, each variable was divided by its maximum value (McCune et al., 2002). The CCA was done on matrices consisting of the 30 roadsides in rows and weighted species abundances and environmental variables in 
columns. The axes used for the CCA ordinations were synthetic linear equations of statistically significant roadside variables detected during the forward selection. The equations were derived to create maximum ordinate space (i.e., correspondence) among species and samples (roadsides). We used Monte Carlo permutation tests $(\mathrm{n}=1000)$ to determine statistical significance of the ordinations. The null hypothesis was that weighted species abundance was not related to gradient changes in roadside variables.

A dry period began in fall 2001 and continued until spring 2002. This allowed landowners to either partially or completely burn, mow and disk several stands of cattail in 15 roadsides. We evaluated the effect of cattail reduction on species compositions by comparing weighted species abundance between 2001 and 2002 on the managed roadsides using the Multiresponse Permutation Procedure (Biondini et al., 1989; Mielke and Berry, 2001). We used the Bray-Curtis distance of weighted species abundance between years and compared these distances against 5000 random permutations using a sequential Bonferroni adjustment (Legendre and Legendre, 1998). We performed the same analysis on the 15 unmanaged roadsides. The analyses were conducted with PopTools 2.6 (Hood, 2004). An Indicator Species Analysis was conducted in PC-ORD to identify species associated with unmanaged roadsides (Dufrene and Legendre, 1997; McCune and Mefford, 1997). Monte Carlo tests (n $=1000$ ) were used to assess significance of the Indicator Species Analysis. Statistical significance for all analyses was $\mathrm{P} \leq 0.05$.

\section{RESUlts}

SPECIES ABUNDANCE

In 2001 we counted 122 birds/10 ha $(\mathrm{SE}=11.4)$ and observed 38 species. Red-winged blackbirds were the most abundant species with $59 / 10$ ha $(\mathrm{SE}=5.8)$. Of the non-Icteridae, song sparrow and common yellowthroat were the most abundant (Table 1). The average number of species documented per roadside was $8.0(\mathrm{sE}=0.64)$. We found 178 active nests of 10 species (Table 2). Brown-headed cowbirds parasitized $25 \%$ of the total 158 red-winged blackbird nests. In 2002 we counted 136 birds/10 ha ( $\mathrm{sE}=13.0)$ and observed 42 species. Brown-headed cowbirds were more numerous in 2002 than 2001, and supplanted yellowheaded blackbirds as the second most abundant species (Table 1). The rankings of frequently encountered non-icterids remained about the same between years. Song sparrow and common yellowthroat maintained their rankings of most abundant of non-icterids. In 2002 the average number of species per roadside was $8.5(\mathrm{sE}=0.65)$. We located 124 active nests of 11 species. Brown-headed cowbirds parasitized $33 \%$ of 87 red-winged blackbird nests.

We counted a total of 45 different species during the study; 31 species were counted in both years. Four species of Icteridae dominated the avifauna, with red-winged blackbirds and brown-headed cowbirds the most abundant species. Densities of brown-headed cowbirds and song sparrows increased between years by $146 \%$ and $94 \%$, respectively; whereas, yellow-headed blackbird densities dropped by 54\%. Of the non-icterids, song sparrow, common yellowthroat, gadwall, mourning dove and blue-winged teal were observed frequently in roadsides. Red-winged blackbird nest density averaged 30/10 ha $(\mathrm{SE}=9.7)$ for 2001-2002. The nest density of red-winged blackbirds dropped by $38 \%$ between 2001 and 2002; whereas, nest density of common grackles increased 7-fold. Of 302 active nests located during the study, $245(81 \%)$ were red-winged blackbird nests.

\section{SPECIES COMPOSITION}

In 2001 cattail stand length and cattail water depth were significant among ten roadside variables. Total cattail stand length was more influential of the two. Relative densities of 
TABLE 2.-Density of nests (per 10 ha) located in $1608-\mathrm{m}$ transects on 30 roadsides with $\geq 200$ linear meters of cattail (Typha spp.) vegetation per transect. The nest surveys were conducted in the Southern Drift Plain of North Dakota's Prairie Pothole Region in 2001 and 2002. Species are listed in descending order by average nest density over the two-year study

\begin{tabular}{lcccccc}
\hline \hline \multirow{2}{*}{\multicolumn{1}{c}{ Species }} & \multicolumn{2}{c}{2001} & & \multicolumn{2}{c}{2002} \\
\cline { 2 - 3 } \cline { 5 - 6 } & Mean & Std. Error & & Mean & Std. Error \\
\hline Red-winged blackbird & 37.0 & & 8.45 & & 23.4 & 9.24 \\
Common grackle & 0.7 & 0.42 & & 4.6 & 4.24 \\
Yellow-headed blackbird & 0.5 & 0.52 & & 1.6 & 1.09 \\
Gadwall & 0.8 & 0.58 & & 0.4 & 0.25 \\
Blue-winged teal & 0.2 & 0.19 & & 0.9 & 0.61 \\
Marsh wren & 0.7 & 0.54 & & 0.4 & 0.27 \\
Unidentified duck & 0.7 & 0.40 & & 0.1 & 0.13 \\
Wilson's snipe & 0 & & & 0.4 & 0.36 \\
Mourning dove & 0.4 & 0.27 & & 0 & \\
Unidentified sparrow & 0 & & & 0.4 & 0.35 \\
Song sparrow & 0.1 & 0.11 & & 0.2 & 0.21 \\
American coot & 0 & 0.17 & & 0 & \\
Killdeer & 0 & & & 0.2 & 0.17 \\
Ring-necked pheasant & 0.1 & 0.13 & & 0.2 & 0.17 \\
Mallard & 0 & & & 0.1 & 0.1 \\
Eastern kingbird & & & & & \\
\hline
\end{tabular}

yellow-headed blackbirds and marsh wrens showed strong direct correlation with cattail stand length; whereas, sora abundance showed strong direct correlation with water depth. The eigenvalues for the first and second axes of the CCA were 0.20 and 0.05 , with about $19 \%$ of the variance in species abundance explained by the axes. The overall CCA and the ordination axes were significant $(\mathrm{P}$ 's $<0.04)$. In 2002 cattail stand length, water depth and live cattail density were significant among the 13 collected roadside variables. Cattail stand length was again the most influential variable, followed by water depth and live cattail density. Marsh wren and killdeer were strongly and directly correlated to total cattail stand length; whereas, American coot, upland sandpiper and gadwall were strongly and directly correlated with density of live cattail stems and cattail stand water depth. Bobolink and western meadowlark were negatively correlated with cattail stand length and water depth. The eigenvalues for the first through third axes were $0.15,0.12$ and 0.08 , respectively. The ordination axes explained about $19 \%$ of the variance in species abundance among roadside transects. The overall CCA and the three ordination axes were significant ( $\mathrm{P}$ 's $\leq 0.04$ ).

Between 2001 and 2002 on managed roadsides, avian species composition changed $(\mathrm{P}=$ 0.02); no change in species composition was detected between years on unmanaged roadsides $(\mathrm{P}=0.35)$. Indicator species of unmanaged roadsides were brown-headed cowbird, common yellowthroat, gadwall and red-winged blackbird (P's $<0.03$ ).

\section{Discussion}

SPECIES ABUNDANCE

Red-winged blackbirds, being habitat generalists and area independent, have adapted well to using roadsides. Indeed, in nearly all published literature involving roadside surveys that assessed avian use or nesting, red-winged blackbirds were the most numerous species (Hergenrader, 1962; Warner, 1992; Camp and Best, 1993; Camp and Best, 1994; Shochat 
et al., 2005). In our surveys the brown-headed cowbird was the second most abundant species for the 2 y combined, although there was large variation in density between years. By comparison, rural roadsides in central Iowa with little or no cattail vegetation harbored the same relative abundances of red-winged blackbirds and brown-headed cowbirds (Camp and Best, 1993); moreover, brown-headed cowbird abundance likewise varied greatly between years.

In the central regions of the U.S., red-winged blackbirds are important nest hosts of brown-headed cowbirds, thus they can be closely associated during the reproductive season (Hergenrader, 1962; Lowther, 1993). Other than an unidentified sparrow nest, brood parasitism by brown-headed cowbirds was exclusive to red-winged blackbirds. We documented an average brood parasitism rate of 28\% for 2001-2002. This percentage was similar to a $27 \%$ parasitism rate of red-winged blackbirds along grassy waterways in Iowa (Bryan and Best, 1994), but generally lower than has been documented in other roadside studies (Hergenrader, 1962; Linz and Bolin, 1982; Camp and Best, 1994). The abundance of brown-headed cowbirds is unknown in studies that focused solely on nesting species (Hergenrader, 1962; Warner, 1992; Camp and Best, 1994). These studies did reinforce the status of red-winged blackbirds as a very abundant roadside-nesting species. For example, $92 \%$ of the nests in central Illinois and $74 \%$ in central Iowa were red-winged blackbird nests (Warner, 1992; Camp and Best, 1994). Much lower percentages for red-winged blackbirds, however, were recorded in eastern and south central Nebraska (34\%) and north central Oklahoma (16\%), with red-winged blackbirds still the most abundant nesting species (Hergenrader, 1962; Shochat et al., 2005).

We counted 10 more species than were counted on similar surveys of Iowa roadsides (Camp and Best, 1993). This difference between studies was due largely to the presence of water and cattail; 17 of the species we counted were identified as wetland - wet meadow species (Igl and Johnson, 1997). In Iowa, only four species were identified as such: killdeer, marsh wren, common yellowthroat and red-winged blackbird. Despite having similar numbers of upland species, the abundance rankings of the non-icterid species were different between the studies in North Dakota and Iowa. In Iowa, vesper sparrows and western meadowlarks were the most abundant non-icterids, reflecting the more xeric roadside environment. The number of song sparrows and vesper sparrows doubled between years in our study and the Iowa study, respectively (Camp and Best, 1993), lending credence to the idea that birds in grassland habitats will respond rapidly to changes in habitat structure that is often brought about by yearly differences in precipitation (Igl and Johnson, 1997; Thogmartin et al., 2006). Lastly, the roadside surveys in Iowa and North Dakota recorded grassland bird species of regional and national conservation concern, as listed by the U.S. Fish and Wildlife Service (USFWS, 2004). The upland sandpiper a species of national conservation concern was observed in both studies; whereas the dickcissel (Spiza Americana) was observed in Iowa, and the grasshopper sparrow and bobolink in North Dakota. The former two species are listed as species of national concern and the latter of regional concern in USFWS Regions 3 and 6.

\section{SPECIES COMPOSITION}

Eigenvalues of the first ordination axes were $<0.30$, which indicated weak separation among species along roadside environmental gradients. This would be expected with bird assemblages consisting of numerous habitat generalists. The narrow linear configuration of roadsides categorizes them as edge habitats, and habitat generalists usually do well in fragmented habitats with large areas of edge. By contrast, many of the grassland bird species in decline need large contiguous blocks of habitat and avoid habitats with high proportions 
of edge. Of the common roadside species detected in our surveys, marsh wrens and yellowheaded blackbirds appeared different than most because they showed a strong correlation across years on cattail stand length. Both are polygynous species and often have territory sizes inversely related to habitat quality (Kroodsma and Verner, 1997; Twedt and Crawford, 1995). Additionally, these species are definitive wetland bird species that require healthy stands of emergent vegetation. The six species of sparrows we observed showed a negative correlation to the statistically significant roadside variables. The vesper sparrow, savannah sparrow and grasshopper sparrow showed the strongest negative correlations to the cattail variables; whereas, song sparrows showed the least consistency in correlations between years. The former three species of sparrows were grassland species generally associated with drier xeric environments. For most species we observed, the correlation in weighted abundance with roadside variables was not consistent across years.

Even though the roadsides were much drier in 2002, most species appeared to track the changes in roadside habitat, shifting more or less proportionately with respect to the origins of the CCA axes. This is befitting of habitat generalists that need behavioral plasticity in a region where cyclic wet and dry periods can profoundly affect the landscape. Cattail stand length had the strongest influence on species compositions followed by cattail stand water depth. These two variables were not necessarily redundant because healthy stands of cattail (especially, hybrid cattail, Typha glauca) can exist in a wide range of water depths ranging from moist soils to 100-cm depths (Waters and Shay, 1992).

The lack of a significant difference in species compositions between years in unmanaged roadsides suggested that management practices such as disking, mowing and burning of roadside cattail probably affected avian use. Cattail stands that were managed were drier than stands on unmanaged roadsides, and the interpretation of the management impact was thus compounded. The CCAs indirectly supported the results of the analyses of effects of cattail reduction on managed roadsides. However, community analyses such as CCA depend only on the characteristics of environmental gradients within the sampled transects in situ. That is, any change in an environmental gradient occurring in a transect (which is in effect what cattail reduction is) gets incorporated within the sampled transect's gradient. Burning and disking does not eliminate the stand itself but does delay the growth of the new cattail shoots and removes the previous years' cattail litter and standing stems. This also destroys the presence of old nests, which may be used as a visual cue of habitat quality by female red-winged blackbirds (Erckmann et al., 1990). Certainly, these factors could influence the abundance of three of the four bird species that were considered indicator species of unmanaged roadsides (common yellowthroats, red-winged blackbirds and, by association, brown-headed cowbirds).

Several waterfowl and wet-meadow species used roadsides with cattail, but none of these species was of either regional or national conservation concern. Roadsides have attracted the interest of resource mangers, who are concerned about declining numbers of grassland bird species in the Central and Great Plains regions of North America. Many grassland bird species of conservation concern prefer large blocks of grassland habitat and, thus, roadsides by themselves can not meet their area requirements (Johnson and Igl, 2001). Augmenting adjacent blocks of grassland habitats by planting native warm-season grasses to replace the cool-season grasses that often dominate roadsides may make roadsides more attractive to area-dependent grassland birds (Camp and Best, 1993). We recognize, however, that roadside environments may be too harsh for warm-season grasses to survive.

Acknowledgments.-A. Galle and C. Lee assisted with data gathering. M. Biondini, J. Church and G. Forcey provided help and insight with statistical analysis. G. Clambey, D. Kirby, G. Neuchterlein and W. 
Thogmartin reviewed earlier drafts of this manuscript. The study was done in partial fulfillment of B. Safratowich's M.Sc. Thesis. This research was supported by the United States Department of Agriculture/Animal and Plant Health Inspection Service/Wildlife Services, North Dakota State University and the National Sunflower Association.

\section{Literature Cited}

Biondini, M. E., A. A. Steuter And C. E. Grygiel. 1989. Seasonal effects on the diversity patterns, spatial distribution and community structure of forbs in the northern mixed prairie, USA. Vegetatio, 85:21-31.

Bryan, G. G. And L. B. Best. 1994. Avian nest density and success in grassed waterways in Iowa rowcrop fields. Wildl. Soc. Bull., 22:583-592.

Camp, M. And L. B. Best. 1993. Bird abundance and species richness in roadsides adjacent to Iowa rowcrop fields. Wildl. Soc. Bull., 21:315-325.

AND - 1994. Nest density and nesting success of birds in roadsides adjacent to rowcrop fields. Am. Midl. Nat., 131:347-358.

Dufrene, M. And P. Legendre. 1997. Species assemblages and indicator species: the need for a flexible asymmetrical approach. Ecol. Monogr., 67:345-366.

Erckmann, W. J., L. D. Beletsky, G. H. Orians, T. Johnsen, S. Sharbaugh and C. D’Antonio. 1990. Old nests as cues for nest-site selection: an experimental test with red-winged blackbirds. Condor, 92:113-117.

GLAHn, J. F. 1974. Study of breeding rails with recorded calls in north-central Colorado. Wilson Bull., 86:206-214.

Hergenrader, G. L. 1962. The incidence of nest parasitism by the brown-headed cowbird (Molothrus ater) on roadside nesting birds in Nebraska. Auk, 79:85-88.

Hood, G. M. 2004. PopTools. Version 2.6.4. http://www.cse.csiro.au/poptools (20 June 2007).

IgL, L. D. And D. H. Johnson. 1997. Changes in breeding bird populations in North Dakota: 1967 to 1992-93. Auk, 114:74-92.

Johnson, D. H. And L. D. IGL. 2001. Area requirements of grassland birds: a regional perspective. Auk, 118:24-34.

Kroodsma, D. E. And J. Verner. 1997. Marsh Wren (Cistothorus palustris). In: The Birds of North America, No. 308. A. Poole and F. Gill (eds.). The Academy of Natural Sciences, Philadelphia, PA: and The American Ornithologists' Union, Washington, D.C.

Legendre, P. And L. Legendre. 1998. Numerical Ecology. $2^{\text {nd }}$ ed. Elsevier Science, Amsterdam, The Netherlands. 870 p.

LinZ, G. M. AND S. B. Bolin. 1982. Incidence of brown-headed cowbird parasitism on red-winged blackbirds. Wilson Bull., 94:93-95.

Lowther, P. E. 1993. Brown-headed Cowbird (Molothrus ater). In: The Birds of North America, No. 47. A. Poole and F. Gill (eds.). The Academy of Natural Sciences, Philadelphia, PA: and The American Ornithologists' Union, Washington, D.C.

McCune, B., J. B. Grace and D. L. Urban. 2002. Analysis of ecological communities. MJM Press, Gleneden Beach, Oregon. 304 p.

AND M. J. MefFord. 1997. PC-ORD. Multivariate analysis of ecological data. Version 3.0. MjM Software, Gleneden Beach, Oregon.

Mielke, P. W., JR. AND K. J. Berry. 2001. Permutation methods: a distance function approach. SpringerVerlag, New York. 352 p.

Palmer, M. W. 1993. Putting things in even better order: the advantages of canonical correspondence analysis. Ecology, 74:2215-2230.

Robel, R. J., J. N. Briggs, A. D. Dayton and L. C. Hulbert. 1970. Relationships between visual obstruction measurements and weight of grassland vegetation. J. Range Manage., 23:295-297.

Shochat, E., D. H. Wolfe, M. A. Patten, D. L. Reinking and S. K. Sherrod. 2005. Tallgrass prairie management and bird nest success along roadsides. Biol. Conserv., 121:399-407.

Stewart, R. E. 1975. Breeding Birds of North Dakota. Tri-College Center for Environmental Studies, Fargo, North Dakota. 295 p. 
TER BRAAK, C. J. F. 1986. Canonical correspondence analysis: a new eigenvector technique for multivariate direct gradient analysis. Ecology, 67:1167-1179.

1995. Ordination, p. 91-173. In: R. H. G. Jongman, C. J. F. ter Braak and O. F. R. van Tongeren (eds.). Data analysis in community and landscape ecology. Cambridge University Press, Cambridge, England. 321 p.

- AND P. SMilauer. 1998. CANOCO reference manual and user's guide to CANOCO for Windows: software for canonical community ordination (version 4). Microcomputer Power, Ithaca, New York. 352 p.

—. AND P. F. M. VERDONSCHOT. 1995. Canonical correspondence analysis and related multivariate methods in aquatic ecology. Aquat. Sci., 57:255-289.

Thogmartin, W. E., M. G. Knutson and J. R. Sauer. 2006. Predicting regional abundance of rare grassland birds with a hierarchical spatial count model. Condor, 108:25-46.

Twedt, D. J. and R. D. Crawford. 1995. Yellow-headed Blackbird (Xanthocephalus xanthocephalus). In: A. Poole and F. Gill (eds.). The Birds of North America, No. 192. The Academy of Natural Sciences, Philadelphia: and The American Ornithologists' Union, Washington, D.C.

U. S. Fish And WiLdlife Service (USFWS). 2004. A blueprint for the future of migratory birds: migratory bird program strategic plan 2004-2014. U.S. Fish and Wildlife Service, Washington, DC. http://migratorybirds.fws.gov/mbstratplan/GPRAMBSpecies.pdf (20 June 2007).

WARNER, R. E. 1992. Nest ecology of grassland passerines on road rights-of-way in central Illinois. Biol. Conserv., 59:1-7.

WATERS, I. AND J. M. SHAY. 1992. Effect of water depth on population parameters of a Typha glauca stand. Can. J. Bot., 70:349-351. 